\title{
POTASSIUM SUPPLEMENTS AND CONGESTIVE HEART FAILURE
}

\author{
BY \\ C. T. G. FLEAR* AND R. H. CAWLEY \\ From the Queen Elizabeth Hospital, Birmingham, and The Institute of Psychiatry, Maudsley Hospital, London \\ Received December 1, 1961
}

A deficiency of potassium is frequently recognized in congestive heart failure: estimates of total exchangeable body potassium are low (Aikawa et al., 1952; Burrows et al., 1954; Moore et al., 1954; Aikawa and Fitz, 1956; Moore et al., 1956; O’Meara et al., 1957; Flear et al., 1958; Birkenfeld et al., 1958). In a series of 33 episodes of congestive heart failure in 32 patients (Flear, 1960a), values were observed as low as 34 per cent of the expected mean normal value for a person of the same sex and height (mean $61 \%$ of normal).

The potassium content of muscle obtained by biopsy may be low (Calhoun et al., 1930; Pilcher et al., 1930; Cort and Matthews, 1954; Cort, 1955; Iseri et al., 1955; Fejfar, 1958; Flear et al., 1961), and retention of potassium has been observed during recovery (Sinclair-Smith et al., 1949; Iseri et al., 1950; Schwartz and Wallace, 1950; Miller, 1951; Squires et al., 1952). In part this overall shortage is due to loss of lean tissue, which may be clinically evident; but there is evidence also of a true cellular deficit (Flear, 1960a; Flear et al., 1961).

It is of interest to enquire to what extent attempts at direct treatment of this manifestation of congestive failure, by oral administration of potassium salts, affect the underlying disorder. There is evidence on general grounds that potassium depletion if allowed to persist may be associated with widespread disturbances and it has sometimes been claimed that potassium supplements produce dramatic improvement where congestive heart failure is intractable (Fox et al., 1949; Cort and Matthews, 1954; Cort, 1955). Others however have been less impressed with the value of potassium supplements (Calhoun et al., 1930; Pilcher et al., 1930; Stock et al., 1951; Elkinton et al., 1952).

The problem of assessing the efficacy of dietary supplements of potassium may ideally be formulated as follows.

Can it be shown that there are any patients in whom clinical improvement is attributable to potassium supplements?

If so, what are the distinguishing characteristics of these patients and of their clinical condition at the time, and to what extent is the prognosis altered?

The present communication reports some observations made in the course of routine clinical practice, in the hope that examination of the results of such observations may throw some light on these questions.

\section{SubJeCtS ANd MethodS}

One hundred and twenty five episodes of congestive heart failure were treated with one or more courses of a potassium salt. One hundred and eighteen of these episodes were from a consecutive series of 397 admissions of 272 patients (Table I; Flear, 1960a). Tables II and III show details of

* Beit Memorial Research Fellow. 
ætiology and clinical features of the treated episodes. In 49 , it was possible to arrange a preliminary control period of at least 7 days (mean 22), during which potassium was withheld. Potassium chloride, citrate, glutamate, or bicarbonate was given by mouth, in doses of not less than $30 \mathrm{mEq}$. a day for not less than 7 days. Estimations of serum electrolytes were carried out immediately before, during, and immediately after the administration of potassium salts.

TABLE I

Constitution of Sample of Patients with Congestive Heart Failure

\begin{tabular}{c|c|c|c|c|c|c|c|c|c}
\hline \multirow{2}{*}{ No. of episodes } & \multicolumn{7}{|c}{ Etiology of congestive heart failure } \\
\cline { 2 - 10 } & \multicolumn{3}{|c|}{ Rheumatic } & \multicolumn{2}{c}{ Non-rheumatic } & \multicolumn{3}{c}{ All patients } \\
\cline { 2 - 10 } & Male & Female & Total & Male & Female & Total & Male & Female & Total \\
\hline 1 & 31 & 50 & 81 & 81 & 39 & 120 & 112 & 89 & 201 \\
\hline 2 & 4 & 16 & 20 & 17 & 7 & 24 & 21 & 23 & 44 \\
\hline 3 & 3 & 4 & 7 & 4 & 5 & 9 & 7 & 9 & 16 \\
\hline 4 & 2 & 2 & 4 & 1 & 0 & 1 & 3 & 2 & 5 \\
\hline 5 or more & 1 & 1 & 2 & 3 & 1 & 4 & 4 & 2 & 6 \\
\hline Total patients & 41 & 73 & 114 & 106 & 52 & 158 & 147 & 125 & 272 \\
\hline
\end{tabular}

TABLE II

Distribution of 125 Episodes of Congestive Cardiac Failure by Ætiology

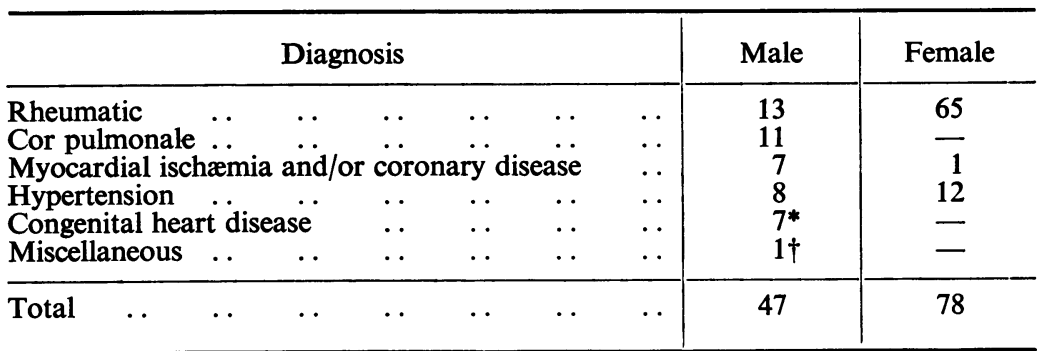

* One patient, 7 admissions-Ebstein's malformation.

$\dagger$ Aneurysm of the sinus of Valsalva.

TABLE III

\begin{tabular}{|c|c|c|c|c|c|c|c|c|c|c|c|}
\hline \multirow[t]{2}{*}{ Etiology } & \multirow{2}{*}{$\begin{array}{l}\text { No. of } \\
\text { episodes }\end{array}$} & \multicolumn{3}{|c|}{$\begin{array}{c}\text { Duration of dyspnœa } \\
\text { (yrs) }\end{array}$} & \multicolumn{3}{|c|}{ Grade } & \multicolumn{3}{|c|}{$\begin{array}{c}\text { Responsiveness to } \\
\text { treatment }\end{array}$} & \multirow{2}{*}{$\begin{array}{l}\text { Atrial } \\
\text { fibril- } \\
\text { lation }\end{array}$} \\
\hline & & 1 or less & \begin{tabular}{|} 
Between \\
$1 \& 5$
\end{tabular} & $\begin{array}{l}\text { More } \\
\text { than } 5\end{array}$ & II & III & IV & Quick & Moderate & $\begin{array}{l}\text { Slow } \\
\text { or nil }\end{array}$ & \\
\hline $\begin{array}{l}\text { Rheumatic } \\
\text { Non-rheumatic }\end{array}$ & $\begin{array}{l}78 \\
47\end{array}$ & $\begin{array}{r}7 \\
19\end{array}$ & $\begin{array}{l}27 \\
12\end{array}$ & $\begin{array}{l}44 \\
16\end{array}$ & $\overline{2}$ & $\begin{array}{l}26 \\
19\end{array}$ & $\begin{array}{l}52 \\
26\end{array}$ & $\begin{array}{r}7 \\
10\end{array}$ & $\begin{array}{r}20 \\
9\end{array}$ & $\begin{array}{l}51 \\
28\end{array}$ & $\begin{array}{l}75 \\
16\end{array}$ \\
\hline Combined & 125 & 26 & 39 & 60 & 2 & 45 & 78 & 17 & 29 & 79 & 91 \\
\hline
\end{tabular}


Our clinical material therefore consisted of, first, a self-controlled study of the effects of potassium salts on the course of 49 episodes; secondly, a biochemical study of a further 76 episodes for which there was no control period; and thirdly, data on outcome and mortality rates in groups treated with and without potassium in the whole series of 397 admissions. The episodes treated respectively with and without potassium supplements were not strictly comparable in all other respects, because the exigencies of the clinical situation did not allow this to be arranged. However, all patients were having digitalis, and a mercurial diuretic was given by intramuscular injection three times a week unless the blood urea exceeded $70 \mathrm{mg}$. per $100 \mathrm{ml}$. (Brenner, 1960). Potassium was given only when it was thought that the patients were not improving clinically, or when it seemed that their condition on admission warranted the exhibition of every measure that could possibly be of value. It is justifiable to conclude that the episodes in which potassium was administered were clinically more severe at the time this treatment was instituted than those in which it was not prescribed.

Criteria for Assessment. In the 49 episodes with a control period before potassium was given, and in the rest of the 125 in which electrolytes were studied, we have tried to assess the influence of potassium supplements upon the course of episodes of congestive heart failure. As an index of the latter, changes in the serum level of sodium have been followed as prognosis correlates well with this level (Flear, 1960a,b). We have also recorded our clinical impressions of whether the patient had improved, remained unchanged, or deteriorated, during the period of administration of potassium salts.

Serum was analysed on admission and at intervals thereafter of not more than one week; more frequently if the patients were remaining unchanged or deteriorating, if serum electrolytes were changing or were very abnormal, or if massive doses of potassium were being given. A change of more than 2.4 per cent was required between two estimates of serum sodium for the difference to be regarded as significant. For potassium the corresponding figure is $4 \cdot 16$ per cent (Appendix).

The 397 episodes for the whole group of patients were classified according to the outcome assessed clinically as follows.

Quick Response. Improvement beginning as soon as patient was put to bed in hospital; free from objective signs of heart failure within three weeks.

Moderate Response. No improvement for a fortnight; all objective signs of heart failure disappearing after a further few weeks.

Slow or Absent Response. No more than gradual improvement and no complete resolution of all signs of heart failure. Loss of œdema (reflected in increased urine output and loss of weight) did not begin for at least six weeks after admission to hospital.

Died in hospital.

\section{RESULTS}

\section{Change in Clinical Condition and Change in Serum Sodium}

In 76 of the 125 episodes in which serum electrolytes were closely followed, serum levels of sodium were initially low (less than $132 \mathrm{mEq}$./litre): in 49 they were normal. The coincidence of fluctuations in clinical condition with variation in serum sodium is shown in Tables IV and V for the two subgroups or episodes, those with and those without hyponatræmia at the beginning of the period. The correspondence between change in serum sodium and alteration in clinical condition-rise and improvement, fall and deterioration, no change in either-is statistically significant in both groups. The impression that serum sodium levels afford a valuable index of the clinical condition and its metabolic concomitants is thereby reinforced. It is thus pertinent to enquire whether a rise in serum sodium occurs more frequently after potassium has been given, and whether a fall in sodium occurs less frequently after potassium. 
TABLE IV

Change in Clinical Condition and Change in Serum Sodium during the

PERIOD WHEN Potassium SALTS WERE TAKen:

EPISODES WITH AN INITIAL HYPONATReMIA

\begin{tabular}{|c|c|c|c|c|c|c|c|}
\hline \multirow{2}{*}{\multicolumn{4}{|c|}{ Clinical condition }} & \multicolumn{3}{|c|}{ Serum sodium } & \multirow{2}{*}{ Total } \\
\hline & & & & \multirow{2}{*}{$\begin{array}{r}\text { Rise } \\
23 \\
3 \\
5\end{array}$} & \multirow{2}{*}{$\begin{array}{c}\text { No change } \\
8 \\
6 \\
8\end{array}$} & \multirow{2}{*}{$\begin{array}{r}\text { Fall } \\
2 \\
4 \\
17\end{array}$} & \\
\hline $\begin{array}{l}\text { Improvement } \\
\text { No change } \\
\text { Deterioration }\end{array}$ & $\begin{array}{l}. . \\
. .\end{array}$ & $\begin{array}{l}. \\
\ddot{.} \\
\end{array}$ & $\begin{array}{l}\cdots \\
\cdots \\
\cdots\end{array}$ & & & & $\begin{array}{l}33 \\
13 \\
30\end{array}$ \\
\hline Total & $\cdots$ & .. & .. & 31 & 22 & 23 & 76 \\
\hline
\end{tabular}

$X^{2}=26 \cdot 77$, d.f. $=4, P<0.005$.

Complete correspondence in $46 / 76=61$ per cent (expected $=35$ per cent).

TABLE V

Change in Clinical Condition and Change in Serum Sodium during the Period When Potassium Salts Were taken: EPISODES WITH AN INITIAL LEVEL OF SODIUM GREATER THAN $132 \mathrm{mEq} . / \mathrm{LITRE}$

\begin{tabular}{|c|c|c|c|c|c|c|c|}
\hline \multirow{2}{*}{\multicolumn{4}{|c|}{ Clinical condition }} & \multicolumn{3}{|c|}{ Serum sodium } & \multirow{2}{*}{ Total } \\
\hline & & & & \multirow{2}{*}{$\begin{array}{c}\text { Rise } \\
5 \\
1 \\
0\end{array}$} & \multirow{2}{*}{$\begin{array}{c}\text { No change } \\
7 \\
4 \\
4\end{array}$} & \multirow{2}{*}{$\begin{array}{r}\text { Fall } \\
8 \\
1 \\
19\end{array}$} & \\
\hline $\begin{array}{l}\text { Improvement } \\
\text { No change } \\
\text { Deterioration }\end{array}$ & $\begin{array}{l}\ldots \\
\cdots \\
\cdots\end{array}$ & $\begin{array}{l}\ddot{ } \\
\ddot{*}\end{array}$ & $\begin{array}{l}\cdots \\
\cdots \\
\cdots\end{array}$ & & & & $\begin{array}{r}20 \\
6 \\
23\end{array}$ \\
\hline Total & .. & $\ldots$ & .. & 6 & 15 & 28 & 49 \\
\hline
\end{tabular}

$X^{2}=14.95$, d.f. $=4, P<0.005$.

Complete correspondence in $28 / 49=57$ per cent (expected $=36$ per cent).

Change in Serum Sodium during Administration of Potassium Salts.

In 49 episodes there was a control period during which potassium was withheld, followed by a period in which potassium supplements were incorporated in the treatment. Table VI shows the changes in serum sodium levels during the course of these two periods. The episodes here have been divided into two groups according to whether or not there was hyponatræmia at the start of treatment with potassium. Examination of Table VI shows that there was an increase in serum

TABLE VI

Changes in Serum Sodium Levels during Control and Treatment Periois: 49 Episodes having Control Period before Start of Potassium Salts

\begin{tabular}{|c|c|c|c|c|c|c|c|}
\hline \multicolumn{4}{|c|}{ Serum sodium } & \multicolumn{2}{|c|}{$\begin{array}{l}\text { Serum sodium less than } 132 \mathrm{mEq} \text {./litre } \\
\text { at start of treatment with potassium } \\
\text { (i.e. end of control period) }\end{array}$} & \multicolumn{2}{|c|}{$\begin{array}{l}\text { Serum sodium } 132 \mathrm{mEq} . / \text { litre or more } \\
\text { at start of treatment with potassium }\end{array}$} \\
\hline & & & & $\begin{array}{l}\text { Without } \\
\text { potassium }\end{array}$ & $\begin{array}{l}\text { With } \\
\text { potassium }\end{array}$ & $\begin{array}{l}\text { Without } \\
\text { potassium }\end{array}$ & $\begin{array}{l}\text { With } \\
\text { potassium }\end{array}$ \\
\hline $\begin{array}{l}\text { Rise ... } \\
\text { No change } \\
\text { Fall } \quad . .\end{array}$ & $\begin{array}{l}. . \\
\because \\
.\end{array}$ & $\begin{array}{l}. . \\
\because \\
\cdots\end{array}$ & $\begin{array}{l}. . \\
\because \\
.\end{array}$ & $\begin{array}{r}3 \\
8 \\
22 \\
\end{array}$ & $\begin{array}{r}18 \\
6 \\
9 \\
\end{array}$ & $\begin{array}{l}3 \\
4 \\
9 \\
\end{array}$ & $\begin{array}{l}3 \\
5 \\
8 \\
\end{array}$ \\
\hline \multirow[t]{2}{*}{ Total } & \multirow[t]{2}{*}{.. } & \multirow[t]{2}{*}{ 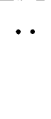 } & \multirow[t]{2}{*}{ 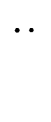 } & 33 & 33 & 16 & 16 \\
\hline & & & & \multicolumn{2}{|c|}{$\begin{array}{l}\mathrm{X}^{2}=16.44 \text { for } 2 \text { d.f. } \mathrm{P}<0.001 \\
\text { Differences highly significant }\end{array}$} & \multicolumn{2}{|c|}{ Differences not significant } \\
\hline
\end{tabular}


sodium in 18 of these 33 episodes after the administration of potassium, as compared with a rise in only 3 after the control period. A fall in serum sodium occurred more commonly in the untreated period. These differences are highly significant statistically. On the other hand, in the 16 episodes not characterized by hyponatræmia when potassium was started, there were no such differences. The conclusion from these data is that potassium supplements seem to be effective in bringing about a rise (or preventing a fall) in serum sodium where there is an initial hyponatræmia, but not where sodium is within normal limits.

Those episodes in which there was a rise in serum sodium following the administration of potassium supplements did not receive significantly different doses of potassium from those in which a rise did not occur.

\section{Change in Serum Potassium during Administration of Potassium Salts}

We may now ask whether a rise in serum potassium occurs more frequently when potassium is given than otherwise, and whether a fall occurs less frequently. Table VII shows the changes in

TABLE VII

Changes in Serum Levels of Potassium following Supplements of Potassium and in Prior Control Period for Episodes in Which Potassium Was initially WithHeld

\begin{tabular}{|c|c|c|c|c|c|}
\hline \multirow{2}{*}{\multicolumn{3}{|c|}{ Serum potassium }} & \multicolumn{2}{|c|}{ Group with control period } & \multirow{2}{*}{$\frac{\text { No control period }}{\text { After potassium }}$} \\
\hline & & & Before potassium & After potassium & \\
\hline $\begin{array}{l}\text { Rise. } \\
\text { No change . } \\
\text { Fall .. }\end{array}$ & $\begin{array}{l}\cdots \\
\cdots \\
\cdots\end{array}$ & $\begin{array}{l}\ldots \\
\cdots \\
\cdots\end{array}$ & $\begin{array}{r}22 \\
18 \\
9\end{array}$ & $\begin{array}{l}21 \\
11 \\
17\end{array}$ & $\begin{array}{l}41 \\
11 \\
24\end{array}$ \\
\hline Total & .. & . & 49 & 49 & 76 \\
\hline
\end{tabular}

Differences not significant.

serum potassium during the initial control period and subsequent period on potassium supplements for the 49 episodes that were subjected to a controlled study. Whilst a rise in serum potassium occurred with the same frequency $(43-45 \%)$ with potassium supplements as without, a fall was observed more frequently when potassium salts were being taken $(35 \%)$ than during the control period $(18 \%)$. When the changes in serum potassium during the control period are compared with changes for episodes treated throughout with potassium, there is again a higher frequency of fall in serum potassium; but in this group there is also a rise in a higher proportion of cases. These figures are difficult to interpret because the most severely ill patients were excluded from the group having a control period. One possible conclusion is that the most severe episodes were characterized by a rising serum potassium level throughout, and that in another group of episodes there was a fall in serum potassium following the administration of potassium salts. On the other hand, the increased frequency of rise in serum potassium may have been induced by potassium salts in these episodes. Patients in whom serum potassium fell or remained unchanged had a slightly lower mean daily dose of potassium (52 and $54 \mathrm{mEq}$. respectively) than did those in whom it rose (60 mEq.).

Table VIII summarizes the changes in serum potassium during the administration of potassium salts in episodes grouped according to their initial serum level of potassium. It is clear that in this series there was no increased likelihood of a rise in serum potassium when levels were already high. Daily potassium supplements were in excess of $40 \mathrm{mEq}$. in all episodes in which serum potassium was more than $5.0 \mathrm{mEq}$./litre. 
TABLE VIII

Changes in Serum Potassium after Administration of Potassium Salts

\begin{tabular}{|c|c|c|c|c|c|c|c|c|c|c|}
\hline \multirow{2}{*}{\multicolumn{7}{|c|}{ Initial serum potassium }} & \multirow{3}{*}{$\begin{array}{r}\text { Total no. } \\
2 \\
3 \\
7 \\
23\end{array}$} & \multicolumn{3}{|c|}{ Change in serum potassium } \\
\hline & & & & & & & & \multirow{2}{*}{$\begin{array}{r}\text { Fall } \\
2 \\
2 \\
3 \\
13\end{array}$} & \multirow{2}{*}{$\begin{array}{c}\mathrm{Nil} \\
0 \\
0 \\
2 \\
3\end{array}$} & \multirow{2}{*}{$\begin{array}{c}\text { Rise } \\
0 \\
1 \\
2 \\
7\end{array}$} \\
\hline $\begin{array}{l}\text { Over } 8 \mathrm{mEq} . / \text { litre } \\
7-8 \mathrm{mEq} . / \text { litre } \\
6-7 \mathrm{mEq} \text { /litre } \\
5-6 \mathrm{mEq} . / \text { litre }\end{array}$ & $\begin{array}{l}. . \\
\ldots \\
\ldots\end{array}$ & $\begin{array}{l}\because \\
\because \\
.\end{array}$ & $\begin{array}{l}\cdots \\
\cdots \\
\cdots \\
.\end{array}$ & $\begin{array}{l}. . \\
\because \\
\because\end{array}$ & $\begin{array}{l}\cdots \\
\cdots \\
\ldots\end{array}$ & $\begin{array}{l}\cdots \\
\cdots \\
\cdots \\
\cdots\end{array}$ & & & & \\
\hline \multicolumn{5}{|c|}{ Total with initial raised serum potassium .. } & .. & .. & 35 & 20 & 5 & 10 \\
\hline \multicolumn{7}{|c|}{ Serum potassium initially less than $5 \mathrm{mEq}$./litre $\ldots$} & 90 & 21 & 17 & 52 \\
\hline
\end{tabular}

TABLE IX

Outcome of Treatment in Groups Treated and not Treated with Potassium Supplements

\begin{tabular}{|c|c|c|c|c|c|c|c|c|c|}
\hline \multirow{2}{*}{ Outcome } & \multicolumn{3}{|c|}{ Men } & \multicolumn{3}{|c|}{ Women } & \multicolumn{3}{|c|}{ Total } \\
\hline & $\begin{array}{l}\text { Without } \\
\text { potassium }\end{array}$ & $\begin{array}{c}\text { With } \\
\text { potassium }\end{array}$ & Total & $\begin{array}{c}\text { Without } \\
\text { potassium }\end{array}$ & $\begin{array}{l}\text { With } \\
\text { potassium }\end{array}$ & Total & $\begin{array}{l}\text { Without } \\
\text { potassium }\end{array}$ & $\begin{array}{l}\text { With } \\
\text { potassium }\end{array}$ & Total \\
\hline $\begin{array}{l}\text { Quick or } \\
\text { moderate } \\
\text { response }\end{array}$ & $\begin{array}{c}107 \\
(68 \%)\end{array}$ & $\begin{array}{c}25 \\
(46 \%)\end{array}$ & $\begin{array}{c}132 \\
(63 \%)\end{array}$ & $\begin{array}{c}88 \\
(72 \%)\end{array}$ & $\begin{array}{c}26 \\
(40 \%)\end{array}$ & $\begin{array}{c}114 \\
(61 \%)\end{array}$ & $\begin{array}{c}195 \\
(70 \%)\end{array}$ & $\begin{array}{c}51 \\
(43 \%)\end{array}$ & $\begin{array}{l}246 \\
(62 \%)\end{array}$ \\
\hline $\begin{array}{l}\text { Survived; } \\
\text { response } \\
\text { slow or } \\
\text { nil }\end{array}$ & $\begin{array}{c}9 \\
(6 \%)\end{array}$ & $\begin{array}{c}8 \\
(15 \%)\end{array}$ & $\begin{array}{c}17 \\
(8 \%)\end{array}$ & $\begin{array}{c}6 \\
(5 \%)\end{array}$ & $\begin{array}{c}19 \\
(30 \%)\end{array}$ & $\begin{array}{c}25 \\
(14 \%)\end{array}$ & $\begin{array}{c}15 \\
(5 \%)\end{array}$ & $\begin{array}{c}27 \\
(14 \%)\end{array}$ & $\begin{array}{c}42 \\
(11 \%)\end{array}$ \\
\hline Died & $\begin{array}{c}41 \\
(26 \%)\end{array}$ & $\begin{array}{c}21 \\
(39 \%)\end{array}$ & $\begin{array}{c}62 \\
(29 \%)\end{array}$ & $\begin{array}{c}28 \\
(23 \%)\end{array}$ & $\begin{array}{c}19 \\
(30 \%)\end{array}$ & $\begin{array}{c}47 \\
(25 \%)\end{array}$ & $\begin{array}{c}69 \\
(25 \%)\end{array}$ & $\begin{array}{c}40 \\
(34 \%)\end{array}$ & $\begin{array}{c}109 \\
(28 \%)\end{array}$ \\
\hline Total & 157 & 54 & 211 & 122 & 64 & 186 & 279 & 118 & 397 \\
\hline
\end{tabular}

TABLE X

Comparison of Mortality Rates in Patients Given and not Given Supplements of Potassium. Patients in both Categories have been Sub-grouped according to the Lowest LeVel to Which their Serum Levels of SODIUM FELL DURING THE ADMISSION

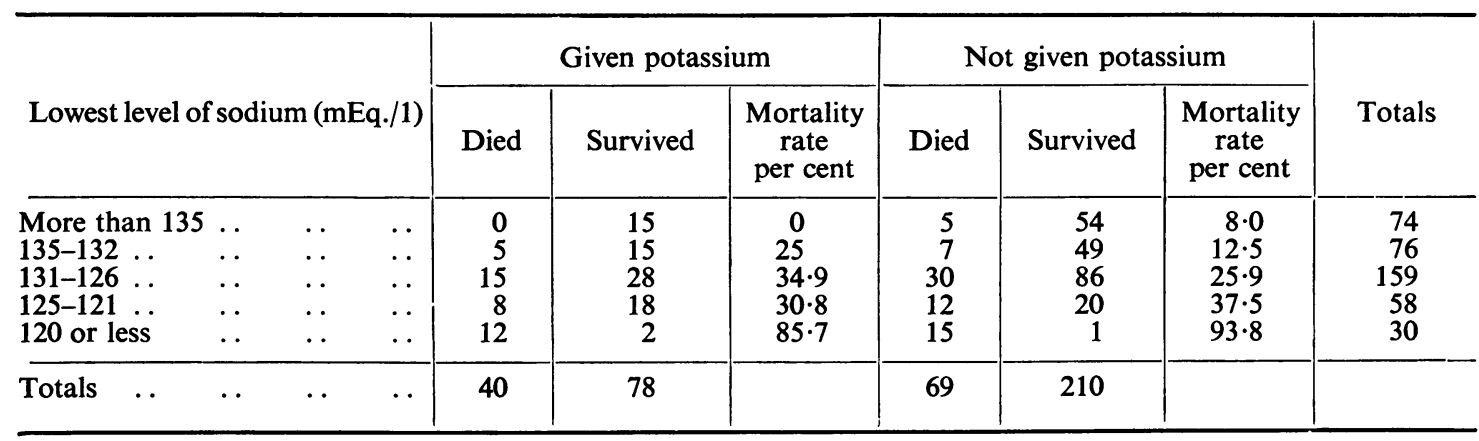


Outcome and Mortality in Relation to Administration of Potassium Salts

Table IX shows the outcome in the whole group of 397 episodes according to whether or not potassium supplements were administered. In both men and women the proportion showing either a quick or a moderate response is higher in the group not treated with potassium than in the treated group. The differences between men and women are not significant; the overall mortality rate was $40 / 118(34 \%)$ in those episodes in which potassium was given, and 69/279 $(25 \%)$ in those in which it was withheld. Interpretation of this difference is difficult as potassium was administered in the more severe episodes. When the treated and untreated groups are further compared after each has been sub-divided according to the lowest level of serum sodium attained during the admission, which gives an approximate impression of severity (Table X), the mortality rate is again higher for the treated group except for the episodes in which hyponatræmia was most severe, in which the treated group appeared to have a better prognosis. None of these differences are significant, but a tentative conclusion from these data is that potassium supplements may be relatively effective in the more hyponatræmia episodes of congestive failure.

A further attempt to compare treated and untreated groups of approximately equal severity is shown in Table XI, where the mortality rate is compared among episodes that responded poorly or

TABLE XI

Mortality Rates in Hospital in Patients in a Severe Episode of Congestive Heart Failure. Patients given Potassium and Patients to Whom Potassium Salts Were not given

\begin{tabular}{|c|c|c|c|c|}
\hline & & & \multicolumn{2}{|c|}{ Potassium supplements } \\
\hline & & & Not given & Given \\
\hline $\begin{array}{llll}\text { Men } & \ldots & \ldots & \ldots \\
\text { Women } & \ldots & \ldots & \ldots \\
\text { Rheumatic (both sexes) } & \ldots \\
\text { Non-rheumatic (both sexes) }\end{array}$ & $\begin{array}{l}\cdots \\
\cdots \\
\cdots\end{array}$ & $\begin{array}{l}\cdots \\
\cdots \\
\cdots \\
\cdots\end{array}$ & $\begin{array}{l}41 / 50(82.0 \%)^{*} \\
28 / 34(82.4 \%)^{\ddagger} \\
23 / 27(85.2 \%)^{*} \\
46 / 57(80.7 \%)^{*}\end{array}$ & $\begin{array}{l}21 / 29(72 \cdot 4 \%)^{*} \\
19 / 38(50 \%) \dagger \\
21 / 33(63.6 \%)^{*} \\
19 / 34(55.9 \%) \ddagger\end{array}$ \\
\hline
\end{tabular}

Differences between those given and those not given supplements of potassium.

* Not significant $(P>0.05)$.

$\dagger$ Significant at 0.5 per cent level $(P<0.005)$.

$\ddagger$ Significant at 5 per cent level $(P<0.05)$.

not at all. Rates for men and women, and for episodes of rheumatic and/or non-rheumatic ætiology are shown separately. In each sub-group, mortality is higher for severe episodes not treated with potassium than for those treated with potassium; these differences are large and statistically significant for women, and for episodes of non-rheumatic ætiology occurring in both sexes.

TABLE XII

Proportion of Severe Episodes in Which Exertional Dyspnoea had been Present for more THAN 5 YeARS ACCORDING TO SEX AND ACCORDING TO ÆTIOLOGICĄ GROUP

\begin{tabular}{|c|c|c|}
\hline & \multicolumn{2}{|c|}{ Potassium supplement } \\
\hline & Given & Not given \\
\hline $\begin{array}{l}\text { Total with failing heart longer than } 5 \mathrm{yr} \text {. } \\
\text { Women with failing heart longer than } \\
5 \text { yr. } \\
\text { Men with failing heart longer than } 5 \text { yr. } \\
\text { Rheumatic (m. \& f.) with failing heart } \\
\text { longer than } 5 \text { yr. } \\
\text { Non-rheumatic (m. \& f.) with failing } \\
\text { heart longer than } 5 \text { yr. }\end{array}$ & $\begin{array}{r}31 / 67(46 \%) \\
18 / 38(47 \%) \\
13 / 29(45 \%) \\
24 / 33(73 \%) \\
7 / 34(21 \%)\end{array}$ & $\begin{array}{l}24 / 84(29 \%)^{*} \\
14 / 34(41 \%) \\
10 / 50(20 \%)^{*} \\
15 / 27(56 \%) \\
9 / 57(16 \%)\end{array}$ \\
\hline
\end{tabular}

* Difference between proportions significant at 5 per cent level. 
It is worth noting that in both men and in patients with rheumatic heart failure the proportion in whom signs of a failing heart (dyspncea on exertion) had been present for more than 5 years was greater in those given potassium than in those to whom supplements were not given (Table XII). In the group of women and the group of both sexes with non-rheumatic ætiology this difference was much smaller.

\section{Discussion}

The problem of assessing the efficacy of dietary supplements of potassium as an adjunct to the treatment of congestive heart failure was formulated in the introduction. This formulation implies that the most appropriate kind of investigation would be by a long-term clinical therapeutic trial, with a series of patients allocated at random to an experimental group, in which potassium supplements were administered, and to a control group treated similarly in all respects save that supplementary potassium was withheld, or alternatively by a trial using a series of pairs of patients comparable to each other in as many respects as possible, one member of the pair having the treatment and one not. The process of administering such a trial with all desirable safeguards against misinterpretation of results would entail dealing with practical difficulties in selection of comparable groups and in choice of criteria of improvement. The former difficulties would be compounded by the progressive nature of the condition both before and after selection. But the most far reaching difficulty in arranging such a controlled trial derives from various ethical considerations.

An essential requirement in the administration of a controlled therapeutic trial is that patients should be allocated completely at random to experimental and control groups. It is accepted by many clinicians that potassium supplements, in appropriate doses, do little or no harm, especially where the facilities of a clinical biochemistry laboratory are available: since congestive heart failure is ultimately fatal in most patients, any measure that is safe may be adopted in an individual case, even if there is no certainty of real benefit. Omission of such a measure or the use of placebos in these circumstances would be regarded, certainly by many clinicians, as unethical. On the other hand, continued administration of potassium supplements in certain situations (that, is, with a rising serum potassium) is held by some to be contra-indicated, and it would by the same token be unethical to keep the patient in a treatment group if one adhered to this view. Moreover, the routine management of congestive failure entails recourse to a number of measures each of which may or may not be indicated in any particular set of circumstances. It would not be possible to arrange for treatment (other than potassium) to be consistently the same for all patients included in the trial, or for alteration in treatment to be applied to members of both experimental and control groups uniformly or at random. The clinician must necessarily be at liberty to invoke and adjust the other forms of treatment appropriately in his management of each individual patient. The effects of this imposition on a trial would be two-fold: first, further variables would be introduced differentially affecting patients included in the trial, so that even larger numbers may be required; second, these variables could not be randomized; the patients who were deteriorating would be likely to have a different pattern of basic treatment from those who were improving, so that differences between the experimental and control groups would probably be diminished to an uncertain extent.

The present study does not conform to the standards of a classical therapeutic trial; the aim was to enquire to what extent examination of the observations made in the context of routine clinical practice could contribute to a critical evaluation of a subsidiary method of treatment.

The decision whether or not to treat episodes of congestive failure with potassium and whether or not an initial control period could be arranged was made on clinical grounds, and potassium was added when it was considered that no further improvement might be expected with the treatment being given or when the patient's condition was considered to warrant the maximum therapeutic intervention. The selection process thereby introduced will bias the results against a favourable impression of the value of potassium.

The clinical evaluations of outcome in the whole series of 397 episodes were made retrospectively as systemic and continuous recording of clinical data in a form suitable for analysis was not 
undertaken in this study. In the smaller series the serum level of sodium was used as an index of the patient's state, a rise being regarded as reflecting improvement. This concept arises from observations of serum levels in all patients admitted in congestive heart failure over a period of several years. It has been noted (Flear, 1960a,b) that prognosis is worse the lower the level of sodium attained during stay in hospital, or indeed the lower the level obtaining on admission. A tendency has also been noted for sodium levels to rise with recovery (Flear, 1960a). We believe, too, that much circumstantial evidence supports the concept that lowering of the sodium level in serum is at least in part caused by cellular changes, themselves a consequence of circulatory failure. The agreement shown in these patients between change in serum sodium and change in clinical condition we believe affords further support for the concept.

The results of both assessments suggest that supplements of potassium are in some cases helpful; immediate mortality may be lessened, and the underlying metabolic disturbance may be favourably influenced. There is evidence that potassium salts are certainly helpful in episodes that are clinically more severe and where the serum levels of sodium are low. Evidence for the efficacy of this adjunct to treatment in less severe cases, and those with normal sodium levels, is less clear. Why only some patients are favorably influenced by potassium supplements, and how to predict those in whom potassium will be effective, are unsolved problems. The question also remains of why some patients deteriorate despite taking supplements in similar dosages to those who apparently respond favourably. Deterioration may perhaps be of myocardial origin or attributable to complications. There is a suggestion that the length of time that the heart has been failing (reflected in the known duration of undue shortness of breath on exertion) may be relevant. Thus the group of men given potassium, and the group of patients of rheumatic ætiology given potassium both contain a higher proportion of episodes in which exertional dyspnœa was present for more than 5 years than do the corresponding groups to whom potassium was not given. This is not so for the groups of women and of patients with non-rheumatic cardiac disease, in whom potassium appeared to improve outcome.

The evidence suggests that potassium salts effected a rise in serum sodium in many of the patients with a low level of sodium, but although there was a suggestion of a similar effect in some patients with normal serum levels the evidence was not significant statistically. Our experience is therefore in accord with that of Laragh (1954) and Laragh and Capeci (1955). Since hyponatræmia is known to arise through the operation of a number of mechanisms, it might well be expected that potassium is only therapeutic in certain circumstances. When the changes in serum sodium levels in the whole series of 125 episodes during potassium administration are compared with changes in the control period for the 49 episodes for which this was arranged (Table XIII) the differences are not significant.

TABLE XIII

Changes in Serum Sodium Levels after Potassium Supplements, and during an Initial Control Period in 49 EPISODES

\begin{tabular}{|c|c|c|c|c|c|c|c|}
\hline \multicolumn{4}{|c|}{ Serum sodium } & \multicolumn{2}{|c|}{$\begin{array}{l}\text { Serum sodium less than } 132 \mathrm{mEq} . / \text { litre } \\
\text { at start of control or treatment period }\end{array}$} & \multicolumn{2}{|c|}{$\begin{array}{l}\text { Serum sodium } 132 \mathrm{mEq} . / \text { litre or more } \\
\text { at start of control or treatment period }\end{array}$} \\
\hline & & & & $\begin{array}{l}\text { Without } \\
\text { potassium }\end{array}$ & $\begin{array}{l}\text { With } \\
\text { potassium }\end{array}$ & $\begin{array}{l}\text { Without } \\
\text { potassium }\end{array}$ & $\begin{array}{l}\text { With } \\
\text { potassium }\end{array}$ \\
\hline $\begin{array}{l}\text { Rise .. } \\
\text { No change } \\
\text { Fall } \quad . .\end{array}$ & $\begin{array}{l}\cdots \\
\cdots \\
\cdots\end{array}$ & $\begin{array}{l}\cdots \\
\cdots \\
\cdots\end{array}$ & $\begin{array}{l}\ldots \\
\cdots \\
\cdots\end{array}$ & $\begin{array}{r}5 \\
7 \\
12\end{array}$ & $\begin{array}{l}31 \\
22 \\
23\end{array}$ & $\begin{array}{r}1 \\
5 \\
19\end{array}$ & $\begin{array}{r}6 \\
15 \\
28\end{array}$ \\
\hline \multirow[t]{2}{*}{$\overline{\text { Total }}$} & \multirow{2}{*}{$\cdots$} & \multirow{2}{*}{$\cdots$} & \multirow{2}{*}{$\cdots$} & 24 & 76 & 25 & 49 \\
\hline & & & & \multicolumn{2}{|c|}{$\begin{array}{l}\mathrm{X}^{2}=4.04 \text { for } 2 \text { d.f., } P>0.1 \\
\text { Differences not significant }\end{array}$} & \multicolumn{2}{|c|}{ Differences not significant } \\
\hline
\end{tabular}


However, if we exclude those episodes in which there was no change in serum sodium, the differences between the initially hyponatræmic episodes, treated and not treated, is statistically significant $\left(\mathrm{X}^{2}=4 \cdot 19\right.$ for 1. d.f. $\left.\mathrm{P}<0.05\right)$. We may justify the exclusion of this group by recalling that there are patients in congestive heart failure, as in other chronic maladies, in whom the level of sodium is persistently low and steady for long periods without apparent ill effects. In those it would be a matter for surprise were the addition of potassium salts to reverse such a well-established and tolerated steady state.

It has been suggested (Laragh, 1954; Laragh and Capeci, 1955) that administered potassium enters cells leading to extrusion of sodium, which is retained in the extracellular fluids with a rise in its level in these fluids. While potassium may well be taken up by cells it is more conjectural whether sodium would leave them in the absence of a potassium depletion or indeed where cellular depletion is due to altered cellular function (Flear, 1960b). In the latter circumstances cells perhaps may not even take up potassium. Conway (1956) has concluded that for the rat a rise in serum potassium is associated with a fall in muscle sodium, and a fall in serum potassium with a rise in muscle sodium. Assuming that a rise in serum sodium in our patients indicates a fall in muscle sodium, no such relationship is apparent in our data (Table XIV).

TABLE XIV

Relationship between Changes in Serum Levels of Sodium and Potassium in Episodes Treated with Potassium SALTS

\begin{tabular}{|c|c|c|c|c|c|c|c|c|}
\hline \multirow{3}{*}{ Serum sodium } & \multicolumn{4}{|c|}{$\begin{array}{l}\text { Initial serum sodium less than } \\
132 \mathrm{mEq} . / \text { litre }\end{array}$} & \multicolumn{4}{|c|}{$\begin{array}{c}\text { Initial serum sodium } 132 \mathrm{mEq} . / \text { litre } \\
\text { or more }\end{array}$} \\
\hline & \multicolumn{3}{|c|}{ Serum potassium } & \multirow[b]{2}{*}{ Total } & \multicolumn{3}{|c|}{ Serum potassium } & \multirow[b]{2}{*}{ Total } \\
\hline & Rise & $\begin{array}{c}\text { No } \\
\text { change }\end{array}$ & Fall & & Rise & $\begin{array}{c}\text { No } \\
\text { change }\end{array}$ & Fall & \\
\hline $\begin{array}{l}\text { Rise } \\
\text { No change } \\
\text { Fall }\end{array}$ & $\begin{array}{l}15 \\
11 \\
17\end{array}$ & $\begin{array}{l}4 \\
4 \\
3\end{array}$ & $\begin{array}{r}12 \\
7 \\
3\end{array}$ & $\begin{array}{l}31 \\
22 \\
23\end{array}$ & $\begin{array}{r}0 \\
6 \\
13\end{array}$ & $\begin{array}{l}3 \\
4 \\
4\end{array}$ & $\begin{array}{r}3 \\
5 \\
11\end{array}$ & $\begin{array}{r}6 \\
15 \\
28\end{array}$ \\
\hline Total & 43 & 11 & 22 & 76 & 19 & 11 & 19 & 49 \\
\hline
\end{tabular}

Potassium salts may help; it is important to know whether they are ever contraindicated, and if so, in what circumstances. Many clinicians have stressed the dangers attending a rise in the serum level of potassium. It is therefore relevant to ask whether the likelihood of a rise in serum level precludes the use of supplements in congestive heart failure where there is already a tendency for the potassium level to rise, and some degree of oliguria. Brown et al. (1951) have submitted that potassium salts are dangerous in patients with heart disease, because of a particular tendency for the serum level to rise following salts. They attribute this rise to poor excretion. However, there is evidence that raised levels in congestive heart failure are not due to an inability to excrete potassium (Flear, $1960 a$ ) and it has been suggested that they may be a consequence of altered equilibria across cell membranes (Flear, 1960a, $b$ ). It may be noted that even very high serum potassium levels (greater than 7.0 mEq./1.) may be present without changes in the electrocardiograph; and Wilde (1957) has even suggested that an induced increase in serum potassium might be beneficial in congestive heart failure when there is hyponatræmia.

The data presented above indicate that fluctuations in serum potassium occur more commonly after administration of potassium salts. There was however a fall in serum potassium as often as a rise. In this respect our data do not agree with those of Laragh (1954). Moreover, in the 62 out of 125 episodes in which there was a rise, the final level of serum potassium was still below $5 \mathrm{mEq}$./litre in 29. The danger of toxic effects appears thus to be very slight; several schools in the 1930s who 
used potassium salts widely and sometimes in very heavy doses, (Barker, 1935; Keith and Binger, 1935) were also impressed with this fact. A rise in the level of potassium may be due to independent deterioration in the patient's condition rather than to additional potassium given by mouth and we believe that the high frequency with which a rise in serum potassium is associated with a fall in sodium level (Table XIV) indirectly supports this view. In 22 of the 49 control periods serum potassium rose; it was accompanied by a fall in sodium in 20 . Large doses of potassium may be given safely and indeed Pitts and Sartorius (1950) in their review on diuretics ascribe much of the apparent lack of success of potassium salts as diuretics in œdematous conditions to inadequate dosage. However, with Laragh (1954), we found no evidence of diuretic response to potassium salts, although our dosages at times were high.

\section{SUMMARY}

There is evidence that dietary supplements of potassium when given as an adjunct to the treatment of congestive heart failure are efficacious in certain circumstances. Mortality rates may be lowered in some groups of patients, and the serum sodium rises, indicating a probable improvement in the associated metabolic disorder.

It is not possible from these studies to define the precise characteristics of episodes of congestive failure that apparently respond to potassium supplements; however the most direct evidence of efficacy of potassium in our series was found in the group of female patients, and in the group of non-rheumatic ætiology. These groups had a lower proportion of patients with a history of 5 years or longer of heart failure (exertional dyspnœa). Episodes characterized by hyponatræmia also seem to respond to potassium supplements. In the group of episodes for which potassium was prescribed, both rises and falls in serum potassium were more common than in the control groups, and falls were as frequent as rises. In those patients in whom there was a rise in serum potassium, dangerous levels were never reached. In these patients the rise in serum potassium is not related to the dosage of potassium salts; it is possibly altogether independent of this treatment. The risks of administering potassium supplements are evidently low.

The results of this study are provisional and approximate. Further studies using more comprehensive methods of observation and measurement of clinical and biochemical variables, and using control periods as well as treatment periods for as many patients as possible, will be required before it is possible to formulate the precise indications for inclusion of potassium supplements in the treatment of congestive failure. It is suggested that in view of the difficulties in arranging and interpreting the results of a fully controlled therapeutic trial, valuable information may be obtained from routine clinical practice by the careful use of a systematic method of recording clinical and other information, and by observing patients whenever possible before, as well as after, the introduction of new regimes of treatment.

\section{APPENDIX}

\section{Errors of Measurement of Sodium Levels of Sodium, Potassium, and Chloride}

On three occasions, at widely separated intervals over the period of this study, a volume of pooled serum was obtained. It was not distinctively labelled and on successive days an aliquot was analyzed for sodium, potassium, and chloride content during the course of other routine determinations from wards in the hospital. The variation observed is summarized below.

\begin{tabular}{c|c|c|c|c}
\hline \multirow{2}{*}{ Serum } & \multirow{2}{*}{$\begin{array}{c}\text { No. of days } \\
\text { analysed }\end{array}$} & \multicolumn{3}{|c}{ Coefficient of variation (\%) } \\
\cline { 2 - 5 } & 13 & $\mathrm{Na}$ & $\mathrm{K}$ & $\mathrm{Cl}$ \\
\hline 1 & 25 & 1.56 & 2.06 & 0.92 \\
2 & 16 & 0.62 & 2.37 & 0.37 \\
3 & & 1.20 & 2.52 & 1.43 \\
Mean & & & 0.93 \\
\hline
\end{tabular}


It is a pleasure to acknowledge the help and encouragement received from Dr. O. Brenner, Physician to the United Birmingham Hospitals. We wish also to thank Professor A. Bradford Hill for his comments on the manuscript; the views expressed however are the responsibility of the authors. The serum biochemistry estimations were carried out by the Department of Biochemistry, the Queen Elizabeth Hospital, Birmingham, to the members of which we are much indebted for their co-operation. In particular we would like to thank Miss Pat Hughes, lately of that department, for her help.

Part of the expenses incurred in this study were met by a grant from Pfizer Ltd., Sandwich.

Some of the material on which this paper is based was included in an M.D. Thesis submitted by one of us (C.T.G.F.) to the University of Birmingham.

\section{REFERENCES}

Aikawa, J. K., and Fitz, R. H. (1956). Circulation, 14, 1093. Felts, J. H., Tyor, M. P., Marrell, G. T. (1952). J. clin. Invest., 31, 743.

Barker, H. (1935). J. Amer. med. Ass., 105, 1590.

Birkenfeld, L. W., Leibman, J., O'Meara, M. P., and Edelman, I. S. (1958). J. clin. Invest., $57,687$.

Brenner, O. (1960). Modern Trends in Cardiology. A. Morgan Jones. London, Butterworth, p. 82.

Brown, H., Tanner, G. L., and Hecht, H. H. (1956). J. lab. clin. Med., 37, 506.

Burrows, B. A., Ashley, M. M., and Sisson, J. H. (1954). Clin. Res. Proc., 1, 31.

Calhoun, J. A., Cullen, G. E., Clarke, G., and Harrison, T. R. (1930). J. clin. Invest., 9, 693.

Conway, E. J. (1956). Memoirs of the Society for Endocrinology No. 5. Ed. I. Chester Jones and P. Eckstein. Cambridge, Cambridge University Press, p. 3.

Cort, J. H. (1955). Acta. med. Acad. Sci. Hung., 8, 347. .

, and Matthews, H. L. (1954). Lancet, 1, 1202.

Elkinton, J. R., Squires, R. D., and Bluemle, L. W. (1952). Circulation, 5, 58.

Fejfar, Z. London, Churchill (1958). Ciba Foundation Colloquia on Ageing. Vol. 4. Water and Electrolyte Metabolism in relation to Age and Sex. Ed. G. E. Wolstenholme and M. O'Connor.

Flear, C. T. G. $(1960 a)$. Studies in Congestive Heart Failure: Therapeutic and Theoretical Problems. M. D. Thesis. Birmingham University. (1960b). Postgrad. med. J., 36, 104.

- Cawley, R. H., Quinton, A., and Cooke, W. T. (1958) Clin. Sci. 17, 81. Florence, I., and Evans, D. (1961). In preparation.

Fox, C. L., Friedburg, C. K., and White, A. G. (1949). J. clin. Invest., 28, 781.

Iseri, L. T., Boyle, A. J., Rosow, W. R., Griffin, R., and Engstrom, F. (1950). J. clin. Invest., $29,825$.

- , Chandler, D. E., Myers, G. B. (1955). Circulation, 11, 615.

Keith, N. M., and Binger, N. W. (1935). J. Amer. med. Ass., 105, 1584.

Laragh, J. H. (1954). J. clin. Invest., 33, 807. and Capeci, N. E. (1955). Amer. J. Physiol., 180, 539.

Miller, G. E. (1951). Circulation, 4, 270.

Moore, F. D., Edelman, I. S., Olney, J. M., James, A. H., Brooks, L., and Wilson, G. M. (1954). Metabolism, 3, 334.

McMurrey, J. D., Parker, H. V., and Magnus, I. C. (1956). Metabolism, 5, 447.

O'Meara, M. P., Birkenfeld, L. W., Gotch, F. A., and Edelman, I. S., (1957). J. clin. Invest., $36,784$.

Pilcher, C., Calhoun, J. A., Cullen, G. E., and Harrison, T. R. (1930). J. clin. Invest., 9, 191.

Pitts, R. F., and Sartorius, O. W. (1950). Pharmacol. Rev., 2, 161.

Schwartz, W. B., and Wallace, W. M. (1950). J. clin. Invest., $29,844$.

Sinclair-Smith, B., Kattus, A. A., Genest, J., and Newman, E. V. (1949). Bull. Johns Hopk. Hosp., 84, 369.

Squires, R. D., Cresley, A. P., Elkinton, J. R. (1952). Circulation, 4, 868.

Stock, R. J., Mudge, G. H., and Nurnberg, M.J. (1951). Circulation, 4, 54.

Wilde, W. S. (1957). Metabolic Aspects of Transport Across Cell Membranes. Ed. Q. R. Murphy. Madison, The University of Wisconsin Press, p. 157. 